\title{
Health Professionals' Attitudes Towards Mental Illness Patients
}

\author{
Monika Natalia, Suryani, Imas Rafiyah \\ Faculty of Nursing, Universitas Padjadjaran \\ Email: nataliamonika96@yahoo.co.id
}

\begin{abstract}
Health workers are people who have knowledge and skills through education and also devoted themselves in the health areas. The attitude of health workers has determined the services to the patient including patients with mental disorders. A negative attitude is one of the elements formed the stigma against ODGJ (mental disorder patients) who is the greatest barrier to the treatment and the development of effective treatments. This study aimed to identify the attitude of health workers to people with mental disorders at Puskesmas Jatinangor. The research used quantitative descriptive with the cross-sectional approach. The research used the technique of total sampling from the population. The sample was all health workers in Puskesmas Jatinangor total of 55 people. Data taken by using the instrument of Mental Illness: Clinician's Attitude Scale (MICA) developed by Gabbidon et al (2013). Data analysis used a descriptive analysis of the attitude in the form of the mean and the presentation. The higher the total score more and showed negative attitudes (stigmatization). The results showed that more than half of the total respondents had a positive attitude tend to value the mean $48.78 \square$ SD 8.993. This can conclude that health workers in Puskesmas Jatinangor had favored attitudes, accepted, and recognized ODGJ. It is recommended to all health workforce would maintain and increase positive attitudes towards ODGJ.
\end{abstract}

Keywords: Attitude, Health Workers, Mental Health Disorder. 


\section{Introduction}

Primary Health Care (PHC) is a primary health service that prioritizes programs in health promotion and illness prevention. The PHC has a main program which includes health promotion, prevention of infectious diseases, maternal and child health, nutrition, medicine, and environmental health. In addition, there is a development program that is tailored to health problems within the PHC. In Jatinangor Health Center, mental health is included in the PHC development program, the program includes early detection and prevention of mental illness. Mental health is very important for the survival of individuals. Individuals who experience mental health problems are called people with mental disorders (ODGJ) which are characterized by impaired behavior, thoughts, and feelings. Mental health is a significant health problem in the world, including Indonesia. Indonesia has 1.7 per mile of 251 million people who suffer from mental disorders. In West Java, the number increased from 296,943 to 465,975 people in 2012. According to data in PHC Jatinangor 2017, there are 66 ODGJ patients.

Analysis from WHO, 24\% of patients seeking treatment in primary health care have been diagnosed with mental disorders. Because of the high number of cases, the Government established a training program for all health workers in handling ODGJ for. People perceived that mental disorders as negative things (danger \& cannot be cured). This is influenced by attitudes which are individual responses to an object, attitudes can be positive and negative.

A positive attitude is shown when individuals have a tendency to approach, like, and have hope in an object. Whereas negative attitudes when individuals tend to avoid, stay away from, dislike, even hate an object. Health workers play a role in the management of mental disorders such as psychological screening, and counseling related to mental health. Therefore, the attitude of health workers greatly influences their services to ODGJ and their families.

According to Putman (2008) research, health workers tended to have a negative attitude towards ODGJ. Supported by Nordt et al (2006) reported more negative attitudes towards mental patients than general patients and there was a great desire to maintain distance. O'Reilly et al (2010) reported that pharmacists also viewed mental disorders as a difficult disease to cure.

The results of interviews conducted by three health workers at the Jatinangor Health Center in January 2018 said that mental patients need special treatment and are different from the usual patients, besides that they feel no need to be afraid of mental patients. This is because mental patients who come to the PHC are usually in a controlled condition, families of patients with mental disorders already understand if they come to the PHCs they are alienating themselves from the crowd before getting health services. However, related to the handling of patients with mental disorders, 2 out of 3 health professionals said that they did not know clearly, and special training related to mental disorders had been carried out, but only for the program leader. This is different from the government's programs in West Java that all Puskesmas in West Java have received training to deal with mental patients.

The results of the discussion with students of Ners fieldwork of class 35 who were practicing mental nursing fieldwork in Cikeruh Village obtained information that there are psychiatric patients (ODGJ) that tied by their family. This case had not been reported and recorded by the Jatinangor Health Center. The condition of the patient is very pity and the patient's house is not feasible. An elderly person lives and takes cares of the patient. The role of health workers includes finding new cases of mental disorder. In this condition there are problems in fulfilling the role of health workers in the mental program, this can be influenced by the attitude of health workers who are less concerned with ODGJ around the PHC.

Researchers were interested in conducting research on the attitudes of health workers towards people with mental disorders in the Jatinangor Health Center. This is because there are problems related to the attitude of health workers in the Jatinangor Health Center. In addition, according to Riskesdas (2013), in the province of West Java, the incidence of mental disorders in this province increases 
from year to year. Jatinangor is one of the built and educated locations of Padjadjaran University as well as an evaluation material related to government training programs for health workers at the PHC.

\section{Method}

The design of this study was descriptive quantitative with the cross-sectional approach. The variable in this study was the attitude of health workers towards people with mental disorders (ODGJ) at the Jatinangor Health Center. The population of this study was all health workers who worked at the Jatinangor Health Center. This study used a total sampling technique, the number of samples equal to the population. The sample in this study were 55 health workers at the Jatinangor Health Center.

This study used Mental Illness: Clinician's Attitude Scale (MICA) instruments made by Kassam et al (2010) and developed by Gabbidon et al (2013). This instrument is intended for general health workers such as doctors, nurses, midwives, and others. MICA instruments consist of 16 items using a Likert scale measuring instrument. The highest total score means a more negative attitude (Kassam et al., 2010). The researcher conducted face validity on 10 other health workers, and the instrument is good to use. Based on the results of the test by Gabbidon et al (2013) stated that MICA proved valid with a value range of $0.32-0.49$ and reliable with a Cronbach value $\square=0.72$ indicating good consistency.

Researchers did data collection by distributing MICA version 4 questionnaires accompanied by informed consent sheet and filling sheets of respondents' demographic data. Furthermore, respondents filled in according to the data requested, then to fill in the questionnaire section respondents chose one of the available answer options by giving a checklist in the appropriate column with the respondent's answer. The questionnaire was filled directly by respondents who were all health workers in the Jatinangor Health Center. The process of collecting data started after getting a recommendation letter from the Puskesmas Jatinangor.

The researcher was accompanied by a research assistant who had previously been given training of filling the instrument and had the role of helping to spread the questionnaire. The researcher and assistant introduced themselves to the respondent. Furthermore, the researcher conducted informed consent by giving an explanation regarding the research. After that, the researchers asked for approval from all health workers at the Jatinangor Health Center to become respondents in this study and gave the consent sheet as a respondent and explained the procedure for filling out the questionnaire. The study was conducted at the Jatinangor Health Center. During the process of filling out the questionnaire, the researcher allowed respondents to ask questions that were not understood by the researcher.

The following are ethical principles applied by researchers in research, which include respect for human dignity, beneficence, and justice. The first principle is to respect human dignity (respect for human dignity). This principle includes the rights of respondents to get information related to research and researchers to value every decision of health workers for availability to be the subject of research without any coercion (autonomy). The second principle is beneficence that refers researchers to maximize goodness and minimize the occurrence of errors that can harm respondents (nonmaleficence). In the third principle, that is, justice means that there is openness and that researchers are fair to all respondents.

Table 1. Characteristic of the respondent $(n=55)$

\begin{tabular}{|c|c|c|}
\hline Characteristic & f & \% \\
\hline Age & & 3.6 \\
\hline Early Adult & 2 & 96.4 \\
\hline Adult & 53 & \\
\hline
\end{tabular}


Monika Natalia: Health Professionals' Attitudes Towards Mental Illness Patients

\begin{tabular}{|c|c|c|}
\hline Elderly & 0 & 0 \\
\hline Sex & & 27.3 \\
\hline Male & 15 & 72.7 \\
\hline Female & 40 & 81.8 \\
\hline Education & 45 & 16.4 \\
\hline Diploma & 9 & 1.8 \\
\hline Bachelor & 1 & \\
\hline Master & & 45.5 \\
\hline Experience in Taking Care & 25 & 54.5 \\
\hline YDGJ & 30 & 3.6 \\
\hline No & & 43.6 \\
\hline Occupation & 2 & 36.4 \\
\hline Physician & 24 & 1.8 \\
\hline Nurse & 20 & 1.8 \\
\hline Midwife & 1 & 1.8 \\
\hline Dentist & 1 & 3.6 \\
\hline Head of PHC & 1 & 1.8 \\
\hline Nutritionist & 2 & 1.8 \\
\hline Health Analyst & 1 & 1.8 \\
\hline Ners ap. Dental & 1 & 1.8 \\
\hline Public Health & 1 & \\
\hline Pharmacy & 1 & \\
\hline Medical Record & & \\
\hline & & \\
\hline
\end{tabular}

Table 2 Health professionals' attitudes toward ODGJ $(\mathbf{n}=\mathbf{5 5})$

\begin{tabular}{|c|c|c|c|c|}
\hline Variable & N & Std. Deviation & Minimum & Maximum \\
\hline Attitudes & 55 & 8.993 & 26 & 64 \\
\hline
\end{tabular}

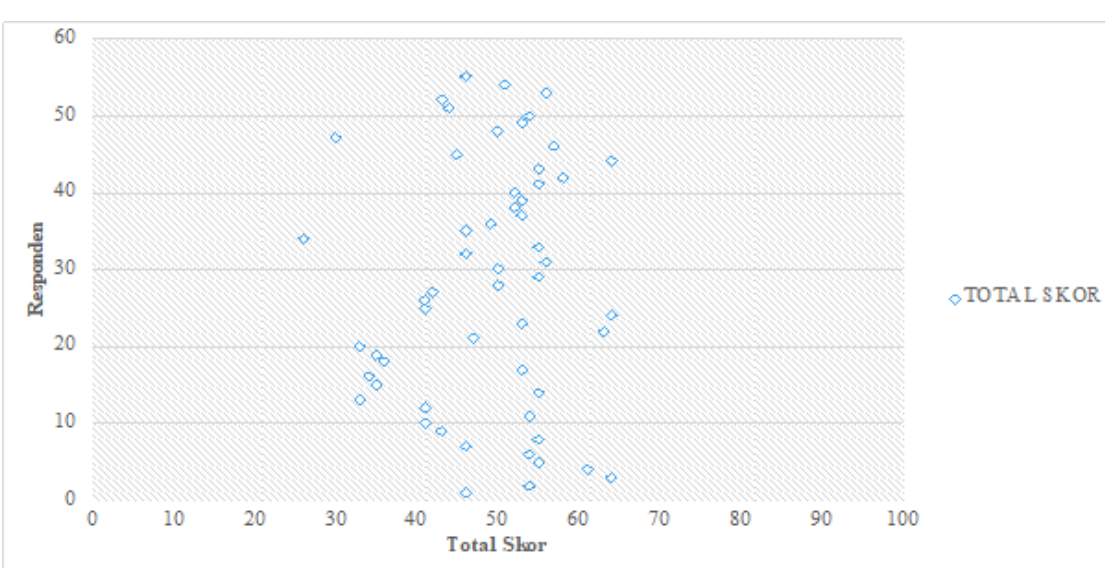

Health professionals' attitudes toward in Scatter diagram 
Table 1 explains that the majority of respondents were female, based on the age of almost all of them were adult respondents, with the educational background was Diploma level. More than half of the total respondents had no experience with ODGJ and less than half of respondents worked as nurses.

\section{Discussion}

Attitude is an individual's internal response that accumulates from several components and is shown in the form of individual behavior towards an object (Pickens, 2005). According to Notoatmodjo (2012), after someone knows about a process object then the individual would judge or behave towards the stimulus. If an individual has a positive attitude towards an object, he would have an attitude that shows, accepts, acknowledges, approves and applies the prevailing norms. Similarly, if the individual has a negative attitude, the individual would reject the prevailing norms. This results in avoidance, exclusion from the environment, and the worst that is the exploitation and discrimination. Negative attitudes and beliefs would lead to negative views (stigma) that distinguish someone from other people (Corrigan et al., 2004).

This study finding was different from the results of the preliminary study to 3 health workers in Jatinangor Health Center. 2 out of 3 people stated that ODGJ should be treated specifically and different from the usual patients. This can be caused by the lack of data obtained. In the study, it was found that more than half of the total respondents had a positive attitude towards ODGJ, although $54.5 \%$ of them did not have experience with ODGJ. This finding contradicts the results of Putman's study (2008) which states that health workers tend to have a negative attitude towards people with mental disorders due to little or no experience with mental patients.

The results of this study showed that the attitudes of health workers towards ODGJ tended to be positive. It can be seen from the lowest mean which most contributes to the total score, especially in statement number 3 which contains equality in the field of mental health with other health fields. According to the results of the study, it can be interpreted that all health workers at the Jatinangor Health Center consider that there is no difference in work in the field of mental health and in other fields. This result is in accordance with Nafsiah (in Prawira, 2014) which states that health workers should not treat patients differently, all patients including ODGJ should be treated as health workers handle other disease patients.

This positive attitude is likely caused by exposure to health workers working at the Jatinangor Health Center with information related to mental disorders and the recovery process. The Puskesmas officers have attended counseling, as well as obtained information related to mental disorders through relatives, mass media, the internet, and others. On the other hand, respondents who still have negative attitudes are likely due to lack of experience and knowledge about ODGJ. Supported by 5 items with the highest average number that contribute to the total score (the higher the more negative), respondents still consider ODGJ dangerous, and uncomfortable interacting with it.

Respondents' attitudes toward mental disorders patients are driven by many factors as described, one of which is knowledge. A person's knowledge of mental disorders contains two aspects, including positive aspects and negative aspects. These two aspects woulddetermineaperson's attitude, the more positive aspects and objects are known, the more positive attitudes toward certain objects will be. Educational background of the respondents was mostly Diploma III, whose education period was dominated by practice compared to theory. However, this factor does not affect respondents to remain positive towards ODGJ.

According to Sartorius (2002), the lack of knowledge and negative attitudes would result in negative behavior towards ODGJ in the form of stigma. Stigma and discrimination against ODGJ is the biggest barrier, effective treatment, and development of care. As for other factors that can influence attitudes towards ODGJ, namely, lack of professional experience, and no familiarity, there are no friends or relatives with mental illness is a factor associated with a more negative and unfavorable attitude (Van der 
Kluit \& Goossens, 2011 ). The attitude of the community towards mental patients is to accept, exclude, discuss and view patients differently from the community (Wawan \& Dewi, 2010).

Nurses are the most dominant health workers in health services. In the field of health, nurses are in charge of providing nursing services and have the responsibility to improve patients' health, prevent disease as well as serving patients who are sick. In the field of mental health nurses have a certain role, namely providing counseling, making appropriate referrals, building cooperation with the patient's family for healing patients and others. A positive attitude is needed so their roles are fulfilled properly.

\section{Conclusion}

This research is a quantitative descriptive study with a sample of 55 health center health workers whose aims to determine the attitudes of health workers towards people with mental disorders in the Jatinangor Health Center. The results of the study show the positive attitudes of health workers towards people with mental disorders in Jatinangor Health Center. This means that respondents have an attitude that tends to support, and accept ODGJ well. This positive attitude would support health services to ODGJ patients with other patients without exclusion, avoidance and even discrimination.

Based on the results, researchers suggested to all health workers to maintain and improve this positive attitude. This can be achieved by the existence of counseling related to ODGJ organized by the PHC and other health service facilities. In order for all health personnel, including those who still have a negative attitude, they can be exposed evenly to all information about ODGJ. This is because health workers should have a positive attitude to all patients, including ODGJ so that the health services provided are fair without differentiation. Researchers suggest to the next researcher to conduct research on factors that can influence the attitudes of health workers towards people with mental disorders in health services. The number of samples is multiplied to get better results.

\section{References}

Ahmead, M. K., Rahhal, A. A., \& Baker, J. A. (2010). The attitudes of mental health professionals towards patients with mental illness in an inpatient setting in Palestine. International journal of mental health nursing, 19(5), 356-362.

Allport, G. W. (1935). Attitudes: A Handbook of Social Psychology, Worcester, Mass. Clark University Press. Anderson, JC, \& Gerbing, DW (1988). Structural equation modeling in practice: A review and recommended two-step approach. Psychological Bulletin, 103(3), 411.

Angermeyer, M. C., \& Dietrich, S. (2006). Public beliefs about and attitudes towards people with mental illness: a review of population studies. Acta Psychiatrica Scandinavica, 113(3), 163-179.

Arvaniti, A., Samakouri, M., Kalamara, E., Bochtsou, V., Bikos, C., \& Livaditis, M. (2009). Health service staff's attitudes towards patients with mental illness. Social psychiatry and psychiatric epidemiology, 44(8), 658-665.

Azwar, S. 2011. Sikap Manusia,Teori dan Pengukurannya. Yogyakarta: Pustaka Pelajar.

Björkman, T., Angelman, T., \& Jönsson, M. (2008). Attitudes towards people with mental illness: a cross-sectional study among nursing staff in psychiatric and somatic care. Scandinavian journal of caring sciences, 22(2), 170-177.

Campos, L., Palha, F., Lima, V. S., Dias, P., Pinhal, A., \& Costa, N. (2011). Attitudes towards people with mental disorders and psychiatry: Impact of mental health residence on a sample of Portuguese medical students.

Centers for Disease Control and Prevention, Substance Abuse and Mental Health Services Administration, National Association of County Behavioral Health \& Developmental 
Disability Directors, National Institute of Mental Health, The Carter Center Mental Health Program. Attitudes Toward Mental Illness: Results from the Behavioral Risk Factor Surveillance System. Atlanta (GA); Centers for Disease Control and Prevention; 2012.

Clement, S., \& Thornicroft, G. (2011). SAPPHIRE program on stigma and discrimination in mental health: research findings. Psychiatrische Praxis, 38(S 01), S07 RE.

Corrigan, P. (2004). How stigma interferes with mental health care. American Psychologist, 59(7), 614.

Corrigan, P., \& Kleinlein, P. (2005). The impact of mental illness stigma. In P. Corrigan (Ed.), On the Stigma of Mental Illness: Practical strategies for research and social change (p.p.11-14). Washington, American Psychological Association.

Departemen Kesehatan Republik Indonesia. (2009). Sistem Kesehatan. Jakarta.

El-Din, M. A., Amen, G. R., ElGhamry, R. H., Mahmoud, D. A., \& Kandel, H. H. (2016). An attitude of medical students toward mentally ill patients: impact of a clinical psychiatric round. The Egyptian Journal of Neurology, Psychiatry and Neurosurgery, 53(1), 6.

Gabbidon, J., Clement, S., van Nieuwenhuizen, A., Kassam, A., Brohan, E., Norman, I., \& Thornicroft, G. (2013). Mental Illness: Clinicians' Attitudes (MICA) Scale-Psychometric properties of a version for healthcare students and professionals. Psychiatry research, 206(1), 81-87.

Haghighat, R. (2005). The development of an instrument to measure stigmatization: factor analysis and origin of stigmatization. The European journal of psychiatry, 19(3), 144154.

Henderson, C., Evans-Lacko, S., \& Thornicroft, G. (2013). Mental illness stigma, help seeking, and public health programs. American journal of public health, 103(5),
777-780.

Horsfall, J., Cleary, M., \& Hunt, G. E. (2010). Stigma in mental health: Clients and professionals. Issues in mental health nursing, 31(7), 450-455.

Ikeme, C. (2012). The stigma of a mental illness label: Attitudes towards individuals with mental illness (Doctoral dissertation, University of Dayton).

Kassam, A., Glozier, N., Leese, M., Henderson, C., \& Thornicroft, G. (2010). Development and responsiveness of a scale to measure clinicians' attitudes to people with mental illness (medical student version). Acta Psychiatrica Scandinavica, 122(2), 153-161.

Kementrian Kesehatan. (2014). Undang - undang No.18 Tahun 2014 Tentang Kesehatan Jiwa. http://hukor.kemkes.go.id/ uploads/rancangan_produk_hukum/UU

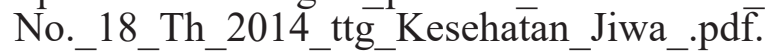
(diakses $20 \overline{\text { Januari }}$ 2018).

Lama, S. (2013). Attitudes and Perceptions of Mental Disorders among Individuals from Nepal.

Lucyati, A. (2014). Penderita Gangguan Jiwa di Jabar Naik 63\%. http://pusdalisbang. jabarprov.go.id/pusdalisbang/infojabar-51. html. 26 Januari 2018.

Maramis, WF. (2006). Ilmu Perilaku dalam Pelayanan Kesehatan. Surabaya: Airlangga University Press.

Marchira, C. R. (2011). Integrasi kesehatan jiwa pada pelayanan primer di indonesia: Sebuah tantangan di masa sekarang. Jurnal Manajemen Pelayanan Kesehatan, 14(03).

Munro, S., \& Baker, J. A. (2007). Surveying the attitudes of acute mental health nurses. Journal of Psychiatric and Mental Health Nursing, 14(2), 196-202.

Notoadmodjo S. Promosi Kesehatan dan Ilmu Perilaku. Jakarta: Rineka Cipta; 2007.

Nordt, C., Rössler, W., \& Lauber, C. (2006). 
Attitudes of mental health professionals toward people with schizophrenia and major depression. Schizophrenia bulletin, 32(4), 709-714.

Nursalam, S. (2013). Metodologi Penelitian Ilmu Keperawatan Pendekatan Praktis.

Pamungkas, D. R., Linawati, O. M., \& Sutarjo, P. (2016). Stigma Terhadap Orang Dengan Gangguan Jiwa (ODGJ) Pada Mahasiswa Program Studi Ilmu Keperawatan Stikes Jenderal Achmad Yani Yogyakarta. Media Ilmu Kesehatan, 5(2), 128-132.

Pickens, J. (2005). Attitudes and perceptions. Organizational behavior in health care, 4376.

Prawira, A. (2014). Tenaga Kesehatan Dilarang Diskriminatif pada Pasien Gangguan Jiwa. https://www.liputan6.com/health/ $\mathrm{read} / 2117433 /$ tenaga-kesehatan-dilarangdiskriminatif-pada-pasien-gangguan-jiwa. 07 Juli 2018 .

Pusat Komunikasi Publik Sekretariat Jenderal Kementerian Kesehatan RI. (2014). Stop Stigma dan Diskriminasi terhadap Orang dengan Gangguan Jiwa (ODGJ). http://www. depkes.go.id/article/view/201410270011/ stop-stigma-dan-diskriminasi-terhadaporang-dengan-gangguan-jiwa-odgj.html. 26 Januari 2018.

Putman, S. (2008). Mental illness: diagnostic title or derogatory term?(Attitudes towards mental illness) Developing a learning resource for use within a clinical call centre. A systematic literature review on attitudes towards mental illness. Journal of psychiatric and mental health nursing, 15(8), 684-693.

Putriyani, D., \& Sari, H. (2016). Stigma Masyarakat Terhadap Orang Dengan Gangguan Jiwa Di Kecamatan Kuta Malaka Kabupaten Aceh Besar. Jurnal Ilmiah Mahasiswa Fakultas Keperawatan, 1(1).

Rao, H., Mahadevappa, H., Pillay, P., Sessay, M., Abraham, A., \& Luty, J. (2009). A study of stigmatized attitudes towards people with mental health problems among health professionals. Journal of psychiatric and mental health nursing, 16(3), 279-284.

Republik Indonesia. 2014. Undang-Undang No.36 Tahun 2014 tentang Tenaga Kesehatan. Lembaran Negara RI Tahun 2009,No.144. Sekretariat Negara. Jakarta.

Sartorius, N. (2002). Iatrogenic stigma of mental illness: begins with behaviour and attitudes of medical professionals, especially psychiatrists.

Sartorius, N. (2007). Stigma and mental health. The Lancet, 370(9590), 810-811.

Sheikh, T. L., Adekeye, O., Olisah, V. O., \& Mohammed, A. (2015). Stigmatisation of mental illness among employees of a Northern Nigerian University. Nigerian medical journal: journal of the Nigeria Medical Association, 56(4), 244.

Sheridan, D. (2012). College students attitudes towards mental illness in relation to gender, self-compassion \& satisfaction with life.

Sugiyono. (2013). Metode Penelitian Pendidikan (Pendekatan Kuantitatif, Kualitatif, dan R\&D). Bandung : Alfabeta.

Suryani, S. (2015). Caring for a Family member With Schizophrenia: The Experience of Family Carers in Indonesia. Malaysian Journal of Psychiatry, 24(1).

Suryani, S., Komariah, M., \& Karlin, W. (2014). Persepsi Keluarga terhadap Skizofrenia. Jurnal Keperawatan Padjadjaran, 2(2).

Suryani. (2013). Mengenal gejala dan penyebab gangguan jiwa. Bandung, Universitas Padjadjaran.

Suryani. (2018). Pendekatan Model Recovery Sebagai Alternatif dalam Penyembuhan dan Pemulihan Gangguan Jiwa Kronis. Bandung, Universitas Padjadjaran.

Svensson, B., Markström, U., Bejerholm, U., Björkman, T., Brunt, D., Eklund, M., ... 
Monika Natalia: Health Professionals' Attitudes Towards Mental Illness Patients

\& Östman, M. (2011). Test-retest reliability of two instruments for measuring public attitudes towards persons with mental illness. BMC psychiatry, 11(1), 11.

Van der Kluit, M. J \& Goossens, P. J. 2011. Factors Influencing Attitudes of Nurses in General Health Care toward Patients with Comorbid Mental Illness: An Integrative Literature Review. Issues in Mental Health Nursing. 32: 519-527.
Wawan, A dan Dewi, M. 2010. Teori dan Pengukuran Pengetahuan, Sikap dan Perilaku Manusia. Yogyakarta: Nuha Medika.

Weret, Z. S., \& Mukherjee, R. (2014). Prevalence of Relapse and Associated Factors in Patient with Schizophrenia at Amanuel Mental Specialized Hospital, Addis Ababa, Ethiopia: Institution. 